\title{
KEEFEKTIFAN VCT DALAM PEMBELAJARAN SEJARAH UNTUK MENINGKATKAN NILAI NASIONALISME, DEMOKRASI, DAN MULTIKULTURAL
}

\author{
Mursetyadi Yuli Sadono, Muhsinatun Siasah Masruri \\ SMA BOPKRI 1 Yogyakarta, Universitas Negeri Yogyakarta \\ sadonoyuli@gmail.com,muhsinsiasah@gmail.com
}

\begin{abstract}
Abstrak
Penelitian ini bertujuan untuk mengetahui keefektifan pembelajaran sejarah dengan menerapkan Value Clarification Technique (VCT) untuk meningkatkan nilai nasionalisme, demokrasi dan multikultural, dengan memperhatikan gaya belajar siswa Visual dan Auditori). Penelitian ini merupakan penelitian quasi eksperiment. Data dianalisis menggunakan analisis faktorial $2 \times 2$ dengan $\alpha=0,05$. Hasil penelitian menunjukan bahwa rerata hasil belajar afektif siswa dengan pembelajaran VCT lebih tinggi daripada siswa yang belajar dengan teknik konvensional $(151,47>138,91 ; \alpha 0,000)$. Kesimpulannya, teknik klarifikasi nilai (VCT) efektif untuk penanaman nilai nasionalisme, demokrasi, dan multikultural melalui pembelajaran sejarah, baik pada siswa yang bergaya belajar auditori maupun visual.
\end{abstract}

Kata Kunci: Keefektifan, VCT, Gaya Belajar

\section{THE EFFECTIVENESS OF VCT IN HISTORY TEACHING TO IMPROVE NATIONALISM, DEMOCRACY, AND MULTICULTURAL VALUES}

Mursetyadi Yuli Sadono, Muhsinatun Siasah Masruri

SMA BOPKRI 1 Yogyakarta, Universitas Negeri Yogyakarta

sadonoyuli@gmail.com, muhsinsiasah@gmail.com

\begin{abstract}
This study aims at investigating the effectiveness of the Value Clarification Technique in history teaching to improve nationalism, democracy, multicultural values by paying attention to students' learning style (visual and auditory).This is a quasi-experimental. The data were analyzed using $t$ test and two-way-variance analysis, $2 \times 2$ with $a=0,005$. The result of analysis shows that The average affective learning achievement of students taught using VCT is higher than that of those taught using the conventional technique $(151.47>138.91 ; \alpha 0.000)$. In conclusion, VCT technique is effective to the growth of nationalism, democracy and multicultural values through history subject learning, good for both students having auditory and visual styles.
\end{abstract}

Keywords: effectiveness, VCT, learning style. 


\section{Pendahuluan}

Meninggalkan abad XX dan memasuki abad XXI, perkembangan masyarakat ditandai dengan mulai munculnya bentuk masyarakat baru, masyarakat informasi (Zamroni, 2007: 18). Perkembangan masyarakat baru, dengan kecenderungan baru ini merupakan tantangan yang harus dihadapi. Berkaitan dengan tantangan jaman yang harus dihadapi oleh bangsa Indonesia, Mochtar Buchori (2000: 35-40, 149150) menyampaikan berbagai permasalahan yang dihadapi masyarakat, dan menjadi tugas dunia pendidikan untuk menjawab tantangan jaman, yaitu: kurangnya kesiapan menghadapi globalisasi, rendahnya mutu tenaga kerja, rendahnya kualitas produk, lunturnya kearifan berbangsa, Ethos kerja yang kurang handal, dan makin lunturnya nasionalisme. Untuk menjawab berbagai permasalahan ini, maka perlu reformasi pendidikan. Tanpa reformasi pendidikan tidak mungkin dilaksanakan reformasi politik, reformasi ekonomi, reformasi sosial. Reformasi berhubungan dengan sikap manusia dan sikap manusia hanya bisa diubah melalui proses pendidikan (Tilaar, 2002 :108).

Irwan Abdullah (2000: 53) menyatakan bahwa kondisi objektif yang dihadapi bangsa Indonesia saat ini merupakan kondisi parah yang dapat dilihat dalam berbagai dimensi persoalan, dari terbatasnya masalah jaminan publik, kualitas manusia yang rendah, konflik dan kekerasan yang mengemuka, hingga kredibilitas pemerintah yang rendah. Permasalahan tersebut hingga saat ini (tahun 2013) masih merupakan permasalahan esensial yang belum terpecahkan. Maraknya berita kejahatan/kriminalitas, kasus pornografi, perkelahian antar pelajar yang semakin marak, dan lain-lain yang sering muncul di media cetak ataupun elektronik menunjukkan kenyataan ini. Hal tersebut menunjukkan betapa rendahnya kualitas moral sebagian masyarakat Indonesia (Darmiyati Zuchdi, 2009: 34). Berkaitan dengan kondisi bangsa Indonesia, Ahmad Syafii Maarif (2001: 6) menyatakan bahwa "Indonesia kini ibarat kapal bocor yang sedang oleng, terapung-apung di laut lepas menunggu karam, sementara nakhodanya seperti tidak punya kompas".

Semangat kebangsaan atau nasionalisme harus dipelihara dan dikembangkan agar relevan dengan tantangan masa kini. Berkaitan dengan konsep nasionalisme, Benedict Anderson (Baskara. 2002) mendefinisikan nasion sebagai “ suatu komunitas politis yang dibayangkan- dan dibayangkan sekaligus sebagai sesuatu yang secara inheren terbatas dan berdaulat (an imagined political community-and imagined as both inherently limited and sovereign). Istilah "dibayangkan" (imagined) karena mengingat bahwa anggota dari nasion itu kebanyakan belum pernah bertemu satu sama lain, tetapi di saat yang sama ada bayangan di benak mereka bahwa mereka ada dalam satu komunitas tertentu.

Di masa Globalisasi ini, perkembangan nasionalisme Indonesia baru dapat dikategorikan sebagai nasionalisme gelombang ketiga. Menurut Anwar Efendi (2011: 16) Nasionalisme gelombang ketiga memiliki karakteristik meliputi (a) Nasionalisme terbuka, (b) Tujuan akhir perjuangan, (c) Kecintaan pada kedamaian, (d) Sejajar dengan bangsa lain, (e) Patriotisme baru, (f) Penguasaan iptek, dan (g) Sikap dan semangat kemandirian.

Nasionalisme yang perlu dikembangkan adalah menjunjung tinggi keragaman budaya. Penanaman nasionalisme, harus disertai dengan penanaman nilai demokrasi dan multikultural. Melalui pluralitas itu, bangsa Indonesia merumuskan kebangsaannya sebagai ikatan yang akan mempersatukan mereka. Dengan demikian identitas nasional mereka hadir tanpa harus membuang identitas lokal yang mereka miliki (abd a'la. 2002:47). Penanaman nasionalisme, harus disertai dengan penanaman nilai demokrasi dan multikultural.

Indonesia sebagai negara yang sedang dalam masa transisi demokrasi, juga mengalami permasalahan yang serius. Permasalahan yang berkaitan dengan proses demokratisasi di Indonesia antara lain: proses demokratisasi yang sangat lambat, belum terciptanya kultur demokrasi dalam masyarakat, kebebasan berekspresi yang belum tumbuh, dan kebiasaan saling menghargai yang kurang. Fakta-fakta di atas merupakan indikasi bahwa kondisi Indonesia sedang terpuruk. Berkaitan dengan kondisi di atas maka perubahan atau pembentukan sikap dan karakter demokratis sangat perlu. Moral education, the founders of our democracy asserted, 
is essential for the success of a democratic society (Lickona.1991:6).

Pendidikan demokrasi perlu dilaksanakan karena proses demokratisasi bangsa ini sangat tergantung pada pendidikan. A democratic state of education constraints choice among good lives not only out of necessity but out of concern for civic virtue (Gutman. 1999:42). Diharapkan dari proses pendidikan yang demokratis ini, akan melahirkan warga negara yang lebih produktif dan efektif dalam kehidupan bermasyarakat, berbangsa dan bernegara (Zamroni.2011: 26). Dengan pendidikan yang demokratis, diharapkan sekolah mampu mencetak generasi mendatang yang berjiwa demokratis, dan tercipta masyarakat yang berkultur demokrasi.

Demokrasi tidak lepas dari multikulturalisme. Berkaitan dengan proses demokratisasi, Indonesia yang bersifat multietnis perlu mengembangkan semangat multikultural, yang menghargai kebhinekaan. Pendidikan kebhinekaan menghargai dan mengakomodasi perbedaan latar belakang seseorang yang menyangkut nilai, budaya, social, ekonomi, bahkan perbedaan dalam kemampuan (Zamroni.2003: 21). Prinsip yang esensial dari multikulturalisme adalah adanya "kesetaraan" . Multikulturalisme secara sederhana dapat dikatakan pengakuan atas pluralisme budaya (Farida Hanum. 2012: 1). Secara sederhana, multikulturalisme dapat dipahami sebagai sikap bagaimana masing-masing kelompok bersedia untuk menyatu (integrate) tanpa mempedulikan keragaman budaya yang dimiliki. Maka perlu dibangun pendidikan multikultural.

Pendidikan multikultur sejalan dengan pengembangan demokrasi. Untuk Indonesia yang bersifat multietnis, pendidikan yang mengedepankan semangat multikultural merupakan kebutuhan yang mendesak. Pendidikan multikultural memiliki berbagai manfaat. Pupu Saeful Rahmat (2007: 3) berpendapat bahwa manfaat utama pendidikan multikultural adalah untuk membangun kohesifitas, solidaritas, dan intimitas di antara keragaman etnik, ras, agama, budaya, dan kebutuhan di antara warga bangsa Indonesia. Pendidikan multikultural menjadi suatu kebutuhan bagi Indonesia, mengingat kondisi Indonesia yang bersifat multikultur. Dalam praktik pendidikan multikultur ada berbagai dimensi. Banks (2007:83) menyatakan :
I have identified five dimensions of multikultural education. They are: (1) Content integration. (2) the knowledge construction process. (3) prejudice reduction. (4) an equity pedagogy, and (5) an empowering school culture and Sosial structure.

Pembelajaran sejarah memiliki relevansi yang penting berkaitan dengan pembentukan karakter bangsa. Pembelajaran sejarah diharapkan dapat mengantarkan peserta didik menjadi warga negara yang kritis dan demokratis, menjunjung tinggi kemerdekaan dan mencintai tanah air, toleransi dan menghargai orang lain, memiliki kearifan, dan kecerdasan sosial (Sardiman AM, 2004: 7). Berkaitan dengan perananya, maka perlu selalu dikembangkan mutu pembelajaran sejarah yang ideal.

Pendidikan sejarah yang ideal adalah pendidikan sejarah yang seharusnya (should to be), "menarik, bermutu tinggi" (Daliman. 2004 :5). Pendidikan sejarah yang ideal, seharusnya kembali kepada pemahaman sejarah secara keseluruhan ialah sejarah manusia atau tepatnya kemanusiaan. Cyriaco E. Kanichai, CMI, 1972 (Daliman, 2004 :6) menyatakan bahwa Pendidikan sejarah mengajarkan kepada kita mengenai apa yang telah dilakukan manusia (it teaches us what man has done), apa yang dapat dilakukan manusia (What man can do), apa yang seharusnya dilakukan manusia (what man should do), dan jadi siapa manusia (an thus what man is). Dari uraian di atas dapat disimpulkan bahwa pendidikan sejarah yang ideal adalah pendidikan sejarah yang menekankan empiris (pengalaman manusia), kontekstual, mengandung nilai-nilai kehidupan (membangun karakter kepribadian seseorang).

Berkaitan dengan penanaman nilai-nilai perlu dipilih teknik yang tepat, agar pembelajaran afektif lebih efektif. Untuk itu teknik klarifikasi nilai atau Value Clarification Technique (VCT) merupakan teknik yang sesuai. Pengertian VCT menurut Sutarjo (2012) adalah teknik pengajaran untuk membantu siswa dalam mencari dan menentukan suatu nilai yang dianggap baik dalam menghadapi suatu persoalan melalui proses menganalisis nilai yang sudah ada dan tertanam dalam diri siswa. Values Clarification is a theory that helps people define their values. The theory assumes that if an individual is successful 
in clarifying his or her own values, then changes in behavior will result (Aram Attarian.1996: 41).

Salah satu karakteristik VCT adalah proses penanaman nilai dilakukan melalui proses analisis nilai yang sudah ada dalam diri siswa kemudian menyelaraskannya dengan nilai-nilai baru yang akan ditanamkan. Pembelajaran VCT dapat dilaksanakan dengan menggunakan berbagai metode seperti Value problem solving, diskusi, dialog, dan presentasi.

Langkah pembelajaran Value clarification technique (VCT) meliputi tujuh tahap yang dibagi ke dalam tiga tingkat. Pertama, Kebebasan Memilih. Pada tingkat ini terdapat 3 tahap, yaitu: a) Memilih secara bebas, siswa diberi kesempatan untuk menentukan pilihan yang menurutnya baik. b) Memilih dari beberapa alternatif. c) Memilih setelah mempertimbangkan berbagai konsekuensi dari masing-masing alternatif. Kedua, Menghargai. Tahap ini terdiri atas dua tahap pembelajaran: 1) Adanya perasaan senang dan bangga dengan nilai yang dipilihnya, 2) Menegaskan nilai yang sudah menjadi bagian integral dalam dirinya di depan umum. Ketiga, berbuat. Tahap ini, terdiri atas: 1) Kemauan dan kemampuan untuk mencoba melaksanakannya. 2) Mengulang perilaku sesuai dengan nilai pilihannya. Artinya, nilai yang menjadi pilihan itu harus tercermin dalam kehidupannya sehari-hari.

Selain pemilihan metode dan teknik yang relevan, guru perlu mengidentifikasi gaya belajar siswa, Gaya belajar seseorang adalah kombinasi dari bagaimana ia menyerap, dan kemudian mengatur serta mengolah informasi (De Porter \& Hernachi, 2002: 110-112). Gaya belajar adalah kunci untuk mengembangkan kinerja dan pekerjaan, kegiatan pembelajaran di sekolah, dan dalam situasi antar pribadi.

Berkaitan dengan penelitian tentang pendidikan karakter, khususnya tentang penerapan VCT, ada beberapa penelitian yang telah dilakukan. Kirscherbaum (2000) menyimpulkan bahwa setiap manusia dalam perkembangan kehidupannya membutuhkan pendidikan nilai untuk mencapai kematangan pribadi, menghindari kemerosotan moral, dan untuk menghindari disintegrasi sosial dalam masyarakat. Acemoglu, Daron., Johnson, Simon., Robinson, James A., et al. (2005) Membuktikan bahwa yang lebih berpengaruh terhadap demokratisasi adalah pendidikan yang demokratis, bukan disebabkan tingkat pendidikan sekolah yang tinggi. Kaitan antara pendidikan dan demokrasi lebih dipengaruhi oleh pendidikan yang demokratis daripada hubungan kausal keduanya. Byford, Jeff \& Russell, William B .(2006: 70-72) menyimpulkan bahwa Penggunaan teknik diskusi untuk pembelajaran ilmu sosial terbukti sebagai metode yang berharga untuk meningkatkan kesadaran siswa dalam bermasyarakat. Hasil penelitian ini memperkuat tentang perlunya mengajaran ilmu-ilmu sosial dengan menggunakan teknik diskusi, yang terbukti dapat membantu siswa untuk mengembangkan dan mempermudah pemahaman tentang isu tertentu, meningkatkan critical thinking skil, dan meningkatkan keterampilan interpersonal. Mosconi, Jacqueline \& Emmett,Judith, Ed.D. (2003: 68-78). menyimpulkan bahwa pembelajaran klarifikasi nilai efektif untuk membantu dalam memahami nilai-nilai, karir masa depan, dan cara-cara mencapai kesuksesan. Penelitian yang dilakukan Sudrajat. (2011) menyimpulkan bahwa dari tiga kali treatment yang dilakukan, terjadi peningkatan kemandirian, kecendekiaan, dan nurani mahasiswa. Berdasarkan penelitian ini, dapat disimpulkan bahwa model pembelajaran VCT dapat menjadi alternatif yang cocok untuk penanaman atau pengembanganan karakter siswa dalam pembelajaran.

Dari hasil penelitian terdahulu dapat disimpulkan, bahwa: 1) Pendidikan nilai sangat dibutuhkan untuk membentuk kepribadian yang matang bagi siswa serta untuk menanamkan berbagai nilai karakter. 2) VCT memiliki efektifitas yang tinggi untuk penanaman nilai karakter dalam pembelajaran, 3) VCT dapat menjadi alternatif yang cocok untuk penanaman karakter siswa melalui kegiatan pembelajaran, 4) VCT sangat menunjang terciptanya iklim pembelajaran yang demokratis. Karena siswa didorong untuk memiliki kebebasan memilih, berekspresi dan mempertanggung-jawabkan pilihannya.

Kondisi siswa di SMA BOPKRI 1 dapat mencerminkan berbagai permasalahan bangsa Indonesia pada umumnya. Berdasar hasil pengamatan, umumnya siswa-siswa SMA BOPKRI 1 memiliki semangat nasionalisme yang rendah. Hal ini nampak dari: sikap apatis terhadap berbagai perkembangan politik, kedisiplinan dalam 
upacara bendera masih kurang, sikap manja, daya juang/militansi rendah, hedonis, kurang memiliki kedisiplinan dan kesadaran hukum, serta kurangnya rasa memiliki terhadap fasilitas umum. Diantara para siswa juga tidak banyak yang memahami nilai-nilai tradisi dan kearifan lokal. Pengaruh budaya barat lebih mendominasi pikiran para siswa mulai dari pola mengkonsumsi makanan, pakaian, dan pola hidup yang cenderung pragmatis.

Semangat multikultural diantara siswa sekolah ini cenderung rendah. Semangat multikultural yang rendah di sekolah ini, ditandai dengan masih adanya perkelahian antar siswa. pola pergaulan yang cenderung terjadi gap-gap yang bersaing tidak sehat, dan masih ada tawuran pelajar dengan sekolah lain. Semangat demokrasi juga dirasakan masih kurang tertanam, sebagai indikasi adalah: kemandirian bekerja rendah, masih adanya pelecehan terhadap sesama siswa karena status ekonomi yang berbeda, terjadi beberapa tindakan bullying, rasa tanggung jawab rendah, dan lain-lain.

Banyak permasalahan yang harus dicari solusi pemecahannya. Dengan demikian pendidikan karakter di sekolah ini perlu ditingkatkan. Permasalahan yang berkaitan dengan kemerosotan karakter bangsa, dapat diidentifikasi dalam pembahasan berikut:1) Krisis kebangsaan (rasa cinta tanah air), yang ditandai dengan banyak remaja di masa kini yang bersikap masa bodoh, sikap apatis terhadap kondisi bangsa, hedonis, dan berpola hidup meniru pola hidup asing (kebarat-baratan). 2) Kurangnya penanaman nilai demokrasi dalam pendidikan di sekolah, 3) Rendahnya semangat multikultur, yang ditandai dengan masih adanya perkelahian dan tawuran antar pelajar, 4) Lunturnya nilai-nilai tradisi dan kearifan lokal, seiring dengan derasnya arus informasi yang diikuti budaya barat yang mendominasi dunia informasi, 5) Kurikulum yang tidak seimbang, lebih menekankan aspek kognitif dan mengesampingkan nilai afektif dan psikomotor, 6) Nilai-nilai nasionalisme, demokrasi, dan multikultural belum terintegrasi dalam kultur sekolah maupun sebagian kegiatan pembelajaran, 7) Lemahnya pendidikan karakter di tingkat sekolah, 8) Pembelajaran VCT untuk penanaman nasionalisme, demokrasi, dan multikultural dalam pembelajaran sejarah belum diterapkan.
Banyaknya permasalahan yang terjadi di SMA BOPKRI 1, penelitian ini dibatasi pada permasalahan: model pembelajaran VCT untuk meningkatkan nilai nasionalisme, demokrasi, dan multikultur dalam pembelajaran sejarah belum diterapkan. Berdasarkan pembatasan masalah tersebut, maka penelitian ini difokuskan pada: Keefektifan pembelajaran VCT (Values Clarification technique), dengan memperhatikan gaya belajar siswa, untuk peningkatan nilai nasionalisme, demokrasi, dan multikultural dalam pembelajaran sejarah, di SMA BOPKRI 1 Yogyakarta.

Penelitian tentang keefektifan penanaman nilai nasionalisme, demokrasi, dan multikultural dalam pembelajaran sejarah di SMA BPKRI 1 Yogyakarta, bertujuan: 1) Mengetahui efektifitas VCT untuk menanamkan nilai nasionalisme, demokrasi, dan multicultural, 2) Mengetahui efektifitas pembelajaran afektif siswa yang memiliki gaya belajar auditori dan gaya belajar visual, baik dengan pembelajaran VCT maupun konvensional, 3) Mengetahui adanya interaksi pengaruh teknik pembelajaran dan gaya belajar terhadap hasil belajar afektif, yang berupa penanaman nilai nasionalisme, demokrasi, dan multikultural. Sedangkan manfaat yang diharapkan dari kegiatan dan hasil penelitian ini adalah: 1) Secara teoritis hasil penelitian ini dapat menjadi salah satu acuan/referensi untuk perencanaan kegiatan pembelajaran sejarah dalam aspek penanaman nilai nasionalisme, demokrasi. dan multikultural dalam diri siswa, 2) Secara empiris, penerapan pembelajaran VCT diharapkan dapat meningkatkan kualitas pembelajaran sejarah, dan dapat menjadi model pendidikan karakter yang terintegrasi dalam mata pelajaran, khususnya mata pelajaran sejarah, 3) Untuk institusi sekolah SMA BOPKRI 1 dan SMA BOPKRI 2 Yogyakarta, hasil penelitian ini diharapkan bermanfaat untuk mengevaluasi dan merancang program kegiatan pembelajara yang lebih berkualitas, serta untuk pengembangan dan peningkatan pelayanan pendidikan yang lebih bermutu.

\section{Metode Penelitian}

Jenis Penelitian

Dilihat dari aspek metode, penelitian ini merupakan jenis penelitian kuantitatif, yaitu jenis quasi experimental. Variabel dalam penelitian ini 
adalah: Variabel bebas (independent variable), variabel kontrol, dan variabel terikat (dependent variable). Variabel bebas $\left(\mathrm{X}_{1}\right)$ dalam penelitian ini adalah teknik pembelajaran yang terdiri atas dua kategori yaitu VCT dan konvensional, sebagai variabel kontrol $\left(\mathrm{X}_{2}\right)$ adalah gaya belajar, Sedang variabel terikat $(\mathrm{Y})$ : adalah hasil belajar afektif yang meliputi: penanaman nilai nasionalisme, demokrasi dan multikultural pada mata pelajaran sejarah.

Waktu dan tempat penelitian

Penelitian dilaksanakan di kelas XI IPA di SMA BOPKRI 1 sebagai kelas eksperimen dan SMA BOPKRI 2 Yogyakarta sebagai kelas kontrol. Penelitian dilaksanakan pada semester genap tahun pelajaran 2012-2013. Waktu penelitian dilaksanakan selama enam bulan dari bulan November 2012 s/d Mei 2013.

Populasi dan Sampel Penelitian

Penentuan populasi penelitian ini adalah dengan populasi target. Dalam penelitian ini, yang menjadi populasi target adalah siswa SMA BOPKRI 1 Yogyakarta dan siswa SMA BOPKRI 2 Yogyakarta, sedangkan populasi terjangkaunya adalah siswa kelas XI IPA BOPKRI 1 Yogyakarta dan siswa kelas XI IPA BOPKRI 2 Yogyakarta. Teknik pengambilan sampel menggunakan purposive sampling, Sebagai sampel adalah kelas XI IPA, dengan kelas eksperimen berjumlah 87 siswa, dan kelas kontrol berjumlah 47 siswa.

\section{Prosedur Penelitian}

Penelitian quasi-experimental ini menggunakan factorial design $2 \times 2$ atau rancangan factorial $2 \times 2$. Desain eksperimen yang digunakan dalam penelitian ini yaitu sebagai berikut.

$$
\begin{array}{|ccc}
\mathrm{T} 1 & \mathrm{Xe} & \mathrm{T} 2 \\
\mathrm{~T} 1 & -\mathrm{Xk}^{-} & -\frac{\mathrm{T} 2}{}
\end{array}
$$

Gambar 6.1. Desain eksperimen

Keterangan:

T1 : tes awal kelompok eksperimen dan kontrol

T2 : tes akhir kelompok eksperimen dan kontrol

$\mathrm{X}_{\mathrm{e}}$ : Perlakuan dengan pembelajaran VCT pada kelas eksperimen.

$\mathrm{X}_{\mathrm{k}}$ : Perlakuan dengan teknik konvensional pada kelas kontrol

\section{Instrumen dan Teknik Pengumpulan Data}

Data yang diambil dalam penelitian ini adalah data pengelompokan gaya belajar siswa dan data hasil belajar afektif siswa. Instrumen penelitian ini menggunakan tes, yaitu tes gaya belajar dan tes hasil belajar afektif. Tes hasil belajar afektif diujikan dalam bentuk pretest dan postest untuk mengukur tingkat afeksi siswa tentang penanaman nilai nasionalisme, demokrasi, dan multikultural. Tes diberikan secara langsung kepada subjek penelitian yaitu siswa klas XI IPA di SMA BOPKRI 1 dan SMA BOPKRI 2 Yogyakarta, sehingga data yang dikumpulkan dalam penelitian ini berupa data primer.

Teknik yang digunakan untuk mengumpulkan data dalam penelitian ini adalah dengan tes. Tes yang digunakan meliputi tes gaya belajar siswa dan tes hasil belajar afektif. Tes hasil belajar afektif digunakan untuk pretest dan postest. Pada kondisi awal kelompok eksperimen diberikan tes awal yang berfungsi sebagai pembanding nilai tes akhir. Soal tes awal dan tes akhir yang diberikan kepada kelompok kontrol sama dengan soal tes awal dan tes akhir yang diberikan kepada kelompok eksperimen. Pengambilan data melalui tes dilakukan sebanyak dua kali bertujuan untuk mengetahui dan membuktikan efektivitas penggunaan metode pembelajaran VCT pada mata pelajaran Sejarah.

\section{Teknik Analisis Data}

Penelitian menggunakan teknik analisis data dengan pendekatan metode kuantitatif, dalam pengolahan data hasil tes awal dan tes akhir. Analisis data menggunakan uji t dan analisis faktorial 2 jalur. Tingkat kepercayaan yang digunakan $95 \%$ atau taraf signifikansi adalah 5\% $(0,05)$. Pengolahan data dan analisis data menggunakan bantuan komputansi program SPSS 17.0 dan program SPSS 19.0, dan uji anova dilakukan dengan bantuan program SPSS 19.0.

\section{Hasil Penelitian dan Pembahasan}

Diskripsi Gaya Belajar Siswa

Berdasar tes gaya belajar, siswa dikelompokkan dalam kategori siswa visual dan siswa auditori. Untuk kelas eksperimen siswa visual sebanyak 42 orang, dan siswa auditori sebanyak 45 orang. Pada kelas kontrol, siswa visual sebanyak 26 orang, dan siswa auditori sebanyak 21 orang. 


\section{Diskripsi Pencapaian Hasil Belajar Afektif}

Berdasarkan data hasil penelitian didapatkan skor hasil belajar untuk kelas eksperimen visual dan kelas eksperimen auditori. dimana untuk kelas eksperimen visual nilai rata-rata postest dan pretest adalah sebesar 151,12 dan 140,56 , sedangkan untuk rata-rata postest dan pretest kelompok eksperimen auditori sebesar 151,89 dan 140,18. Berikut hasil analisis statistik selengkapnya.

Tabel 1. Perbandingan Hasil Pretest dan Posttest Kelas Eksperimen

\begin{tabular}{lccc}
\hline \multicolumn{1}{c}{ Jenis Tes } & N & Mean & STD \\
\hline Pretest kelas Visual & 41 & 140,56 & 10,86 \\
Pretest kelas Auditori & 41 & 140,18 & 9,98 \\
Postest Kelas Visual & 45 & 151,12 & 10,38 \\
Postest Kelas Auditori & 42 & 151,89 & 9,59 \\
\hline
\end{tabular}

Perbandingan hasil postest antara kelompok eksperimen dengan kelompok kontrol visual dapat dilihat pada tabel berikut.

Tabel 2. Rangkuman Perbandingan Hasil Analisis Deskriptif Data Posttest Kategori Gaya Belajar Visual

\begin{tabular}{lcc}
\hline & Eksperimen & Kontrol \\
\hline Mean & 151,02 & 142,77 \\
Median & 150,00 & 146 \\
Modus & 147 & 146 \\
STD & 10,27 & 9,09 \\
Varians & 105,49 & 82,66 \\
Skor Min. & 131 & 118 \\
Skor Maks. & 183 & 155 \\
Sum & 6343 & 3712 \\
\hline
\end{tabular}

Berdasarkan data rangkuman hasil analisis statistik deskriptif pada tabel di atas, dapat diketahui bahwa skor kelompok eksperimen visual lebih tinggi dibanding kelompok kontrol. Hal itu dapat ditunjukkan pada hasil skor minimum, skor maksimum, dan rerata hasil postest visual yang lebih tinggi dari pada skor postest kelompok kontrol. Pada kelompok eksperimen visual dengan penerapan pembelajaran VCT diperoleh skor minimum 131, skor maksimum 183, dan rerata 151,02 . Sedangkan pada kelompok kontrol dengan tanpa perlakuan (teknik konvensional) lebih rendah, yaitu dengan skor minimum 118 skor maksimum 155 , dan rerata 142,77 .
Perbandingan hasil postest antara kelompok eksperimen dengan kelompok kontrol auditori dapat dilihat pada tabel berikut.

Tabel 3. Rangkuman Perbandingan Hasil Analisis Deskriptif Data Posttest Kategori Gaya Belajar Auditori

\begin{tabular}{lcc}
\hline & Eksperimen & Kontrol \\
\hline Mean & 151,89 & 134,14 \\
Median & 151 & 135 \\
Modus & 143 & 122 \\
STD & 9,59 & 9,41 \\
Varians & 91,96 & 88,53 \\
Skor Min. & 133 & 122 \\
Skor Maks. & 175 & 148 \\
Sum & 6835 & 2817 \\
\hline
\end{tabular}

Berdasarkan rangkuman hasil analisis statistik deskriptif tabel di atas, diketahui bahwa terdapat perbedaan perolehan skor antara kelompok eksperimen auditori dibanding kelompok kontrol. Hal itu ditunjukkan dengan skor minimum, skor maksimum dan rerata hasil postest kategori gaya belajar auditori. Pada kelompok eksperimen kategori gaya belajar auditori memiliki skor minimum 133, skor maksimum 175 dan rerata 151,89 . Sedangkan pada kelompok kontrol lebih rendah, yang terbukti dengan perolehan skor minimum 122, skor maksimum 148 , dan rerata 134,14. Sehingga dapat disimpulkan bahwa pada kelompok siswa yang memiliki gaya belajar auditori, penerapan pembelajaran VCT mampu meningkatkan prestasi belajarnya.

Perbandingan Skor Postest Hasil Belajar Kelompok Eksperimen dan Kontrol dapat dirangkum dalam table berikut.

Tabel 4. Rangkuman Perbandingan Hasil Analisis Deskriptif Data Posttest Eksperimen dan Kontrol

\begin{tabular}{lcc}
\hline & Eksperimen & Kontrol \\
\hline Mean & 151,47 & 138,91 \\
Median & 150 & 141 \\
Modus & 147 & 146 \\
STD & 9,88 & 10,11 \\
Varians & 97,53 & 102,21 \\
Skor Min. & 131 & 118 \\
Skor Maks. & 183 & 155 \\
Sum & 13178 & 6529 \\
\hline
\end{tabular}


Berdasarkan rangkuman hasil analisis statistik deskriptif di atas, diketahui bahwa terdapat perbedaan perolehan skor antara kelompok eksperimen dibanding kelompok kontrol. Hal itu ditunjukkan dengan skor minimum, skor maksimum dan rerata hasil postest kelompok eksperimen yang lebih tinggi. Pada kelompok eksperimen memiliki skor minimum adalah 131, skor maximum 183 dan rerata 151,47. Skor yang dihasilkan kelompok kontrol lebih rendah, dengan perolehan skor minimum 118, skor maksimum 155 dan rerata 138,91.

Berikut adalah rangkuman skor tes Hasil belajar afektif:

Tabel 5. Skor Tes Hasil Belajar Afektif

\begin{tabular}{lrcr}
\hline & VCT & Konvensional & Rerata \\
\hline Gaya Auditori & 151,89 & 134,14 & 147,87 \\
Gaya Visual & 151,02 & 142,77 & 146,24 \\
Rerata & 151,47 & 138,91 & 147,07 \\
\hline
\end{tabular}

Dari Rekapitulasi hasil analisis data di atas, dapat dapat diperoleh gambaran tentang efektifitas pembelajaran dengan penerapan VCT, dibandingkan dengan teknik konvensional dan serta pengaruh gaya belajar dalam penanaman nilai nasionalisme, demokrasi, dan multikultural melalui pembelajaran sejarah.

Uji Hipotesis dan pembahasan

Hipotesis pertama berbunyi: Pencapaian hasil belajar afektif dengan menerapkan pembelajaran VCT lebih efektif dibanding pembelajaran konvensional untuk penanaman nilai nasionalisme, demokrasi dan multikultural dalam pembelajaran sejarah. Diketahui bahwa nilai rata-rata postest untuk kelompok siswa yang menerapkan pembelajaran VCT sebesar 151,47, sedangkan kelompok yang menggunakan pembelajaran konvensional sebesar 138,91. Hasil uji statistik menggunakan uji $\mathrm{F}$ diketahui nilai signifikansi $F$ teknik sebesar 0,000 . Kriteria yang digunakan adalah apabila nilai signifikansi $<0,05(\alpha=5 \%)$ maka terdapat kenaikan yang signifikan. Nilai signifikansi ditemukan sebesar 0,000, sehingga $<0,05$. Ini berarti penerapan pembelajaran VCT lebih efektif daripada teknik konvensional dalam meningkatkan penanaman nilai nasionalisme, demokrasi dan multikultural.
Proses belajar mengajar menerapkan VCT lebih efektif karena hal-hal berikut.

a. VCT dengan langkah-langkah yang dilakukan bersifat Student centered, dan menciptakan iklim demokrasi dalam pembelajaran. Penerapan pembelajaran VCT memberi kebebasan siswa. Mereka diberi kebebasan untuk memilih dan menentukan nilai yang lebih diyakininya, setelah itu, mereka dibimbing untuk berargumen dan menarik kesimpulan. Dengan kebebasan ini siswa dapat juga memilih cara belajar, menghayati nilai yang dipilih, dan mengakses suatu informasi sesuai dengan potensi/ gaya belajarnya. Hal ini membuat mereka lebih optimal dalam menghayati nilai-nilai yang terkandung dalam suatu peristiwa atau masalah, sehingga nilai-nilai afektif dapat tertanam lebih efektif dibanding dengan penerapan teknik konvensional.

b. VCT lebih mendorong siswa untuk menghargai nilai-nilai. Dalam teknik VCT siswa diberi kebebasan untuk menentukan nilai yang diyakininya, dengan mempertimbangkan berbagai alternatif nilai dan konsekuensinya. Mereka akan lebih menghargai nilai hasil pilihannya.

c. VCT memberi kesempatan pada siswa untuk merefleksikan nilai-nilai yang sudah dimiliki dan diyakini. Sebelum memilih di antara nilai-nilai yang berhasil diekplorasi, siswa mempertimbangkan berbagai konsekuensi, dan merefleksikan nilai yang diyakini.

d. Pada proses pembelajaran konvensional, meskipun dengan penerapan belajar aktif dengan metode ceramah bervariasi, diskusi, dan penugasan, namun penekanan siswa untuk memilih dengan bebas dan penekanan pada aspek penanaman nilai karakter kurang diperhatikan. Langkah-langkah yang dilaksanakan dalam teknik pembelajaran kurang menciptakan iklim kebebasan dan menyentuh nilai-nilai yang sudah dimiliki dan dipahami siswa, Sehingga nilai-nilai yang ditanamkan melalui teknik pembelajaran konvensional akan lebih menekankan pada pengetahuan, dan indoktrinasi guru. 
Hipotesis kedua: dengan VCT maupun konvensional, pencapaian hasil belajar afektif siswa auditori lebih efektif daripada siswa visual. Berdasarkan hasil analisis diketahui bahwa nilai rerata postest kelompok yang memiliki gaya auditori sebesar 147,87, sedangkan kelompok yang memiliki gaya visual sebesar 146,24 . Hasil uji statistik menggunakan uji $\mathrm{F}$ diketahui nilai signifikansi $\mathrm{F}$ gaya sebesar 0,029 . Kriteria yang digunakan adalah apabila nilai signifikansi $<0,05$ $(\alpha=5 \%)$ maka terdapat kenaikan yang signifikan. Nilai signifikansi ditemukan sebesar 0,029 sehingga $<0,05$. Artinya, bahwa hasil belajar afektif siswa auditori, dengan penerapan VCT maupun teknik konvensional lebih efektif dibanding siswa visual.

Penggunaan VCT maupun teknik konvensional, pencapaian hasil belajar afektif untuk siswa auditori lebih efektif dibanding siswa visual. Hal ini sangat dimungkinkan karena selama proses pembelajaran khususnya pembelajaran konvensional, siswa banyak mendengarkan penjelasan guru (teacher centered), dan dalam kegiatan pembelajaran kurang menggunakan media visual.

Hipotesis ketiga sampai dengan enam digunakan uji Scheffe dengan rangkuman sebagaimana pada tabel sebagai berikut:

Tabel 6. Hasil uji Scheffe

\begin{tabular}{lll}
\hline Teknik/gaya & \multicolumn{1}{c}{ Kelompok } & $\begin{array}{c}\text { Beda } \\
\text { Rerata }\end{array}$ \\
\hline VCT & Auditori vs visual & 0,86 \\
Konvensional & Auditori vs visual & $-8,63^{* *}$ \\
Auditori & VCT vs Konvensional & $17,75^{* * *}$ \\
Visual & VCT vs Konvensional & $8,35^{* *}$ \\
\hline${ }^{* * * *}$ signifikan pada level 1\% & \\
${ }^{* * *}$ signifikan pada level 5\% &
\end{tabular}

Hipotesis ketiga berbunyi: dengan VCT, pencapaian hasil belajar afektif siswa auditori lebih tinggi daripada siswa visual. Diketahui bahwa terdapat perbedaan rerata hasil belajar afektif sebesar 0,86. Berdasarkan uji Scheffe beda rerata sebesar itu tidak signifikan pada alpha $5 \%$, Ini berarti bahwa, pencapaian hasil belajar afektif dengan penerapan pembelajaran VCT untuk siswa auditori relatif sama atau tidak lebih efektif dibanding siswa visual. Hasil analisis ini membuktikan bahwa VCT efektif untuk digunakan sebagai teknik pembelajaran bagi siswa visual ataupun auditorial. Hal ini dikarenakan dalam pembelajaran VCT, terdapat bagian-bagian yang memungkinkan siswa dengan gaya belajar auditori maupun visual dapat melaksanakan proses pembelajaran lebih mendalam dan bermakna. VCT dapat digunakan sebagai teknik pembelajaran afektif yang cocok bagi siswa visual ataupun siswa auditori. Hal ini disebabkan sebagai berikut; a) Dalam pembelajaran VCT, terdapat bagian-bagian yang memungkinkan siswa auditori maupun visual melaksanakan proses pembelajaran lebih mendalam dan bermakna.; b) VCT dapat menggunakan metode yang bervariasi untuk memenuhi kebutuhan belajar siswa auditori maupun siswa visual.

Hipotesis keempat berbunyi: dengan pembelajaran teknik konvensional, pencapaian hasil belajar afektif siswa auditori lebih tinggi daripada siswa visual. Diketahui bahwa terdapat perbedaan rerata hasil belajar afektif sebesar $-8,63$. Berdasarkan hasil uji Scheffe, beda rerata sebesar itu signifikan pada tingkat kesalahan 5\%. Nilai rerata bernilai negatif, berarti kelompok visual memiliki nilai hasil belajar afektif yang lebih tinggi dibandingkan kelompok auditori. Fakta analisis menunjukkan bahwa prestasi hasil belajar afektif siswa auditori lebih rendah dibanding siswa visual. Hal ini dimungkinkan karena metode yang dipakai oleh guru lebih dominan pada metode yang menunjang aspek visual seperti memperagakan, mendemonstrasikan, pemutaran film,dan lain-lain.

Pada pembelajaran konvensional, siswa yang memiliki gaya belajar visual dapat mencapai hasil belajar afektif lebih tinggi dibandingkan siswa auditori. Hal ini dapat terjadi karena berbagai kemungkinan berikut: a) Keefektifan suatu pembelajaran dipengaruhi berbagai faktor, seperti faktor sikap guru, pemilihan metode dan teknik yang tepat, kultur sekolah, lingkungan, latar belakang sosial-ekonomi para siswa, dan lain-lain.; b) Metode yang dipakai oleh guru lebih dominan pada metode yang menunjang aspek visual seperti mendemonstrasikan, memperagakan, pemutaran film, dan lain-lain.

Hipotesis kelima berbunyi: pencapaian hasil belajar afektif untuk siswa auditori, VCT 
lebih efektif daripada teknik konvensional. Diketahui bahwa terdapat perbedaan rerata hasil belajar afektif pada siswa dengan gaya belajar auditori sebesar 17,75. Berdasarkan hasil uji Scheffe beda rerata sebesar itu signifikan pada tingkat kesalahan $1 \%$. Ini berarti pencapaian hasil belajar afektif untuk siswa yang bergaya belajar auditori, pembelajaran VCT lebih efektif dibanding teknik pembelajaran konvensional. Pembelajaran VCT dengan menerapkan metode tertentu cocok digunakan untuk siswa dengan gaya belajar auditori. Siswa auditori lebih dapat menangkap materi jika disajikan dengan metode ceramah bervariasi, curah pendapat (brain stroming), wawancara, atau diskusi terpimpin karena mereka dapat belajar dengan cara mendengarkan.

Untuk siswa auditori pembelajaran VCT lebih efektif dibanding teknik konvensional, karena dalam pembelajaran VCT ada langkahlangkah yang sangat mendukung untuk siswa auditori, yaitu mendiskusikan dan mempresentasikan nilai yang dimiliki, diyakini, dan menjadi pilihannya.

Hipotesis keenam berbunyi: pencapaian hasil belajar afektif untuk siswa visual, pembelajaran VCT lebih efektif daripada teknik konvensional. Terdapat perbedaan rerata hasil belajar afektif siswa dengan gaya belajar visual sebesar 8,35. Berdasarkan hasil uji Scheffe beda rerata sebesar itu signifikan pada tingkat kesalahan 5\%, Maka hipotesis diterima. Pembelajaran afektif untuk siswa visual, pembelajaran VCT lebih efektif dibanding pembelajaran konvensional.

Alasan mengapa penerapan VCT untuk siswa visual dapat mencapai hasil belajar afektif lebih efektif, adalah adanya kebebasan memilih dan berargumentasi secara otentik. Kebebasan memilih ini yang dilanjutkan diskusi dan berargumentasi baik secara kelompok atau klasikal bertujuan untuk tukar-menukar gagasan, hasil penghayatan, dan tukar-menukar pengalaman, sehingga muncul penghargaan terhadap keberagaman masing-masing siswa. Keunggulan VCT adalah dalam hal menciptakan kebebasan siswa untuk berekspresi dan menentukan nilai-nilai secara bertanggung jawab, sehingga teknik ini efektif untuk penanaman afeksi.

Hipotesis ketujuh menyatakan bahwa, terdapat interaksi pengaruh teknik pembelajaran dan gaya belajar siswa terhadap hasil belajar afektif, berupa penanaman nilai nasionalisme, demokrasi dan multikultural. Hasil uji statistik menggunakan uji $\mathrm{F}$, diketahui nilai signifikansi $\mathrm{F}$ interaksi teknik dan gaya (teknik dan gaya) sebesar 0,008. Kriteria yang digunakan adalah apabila nilai signifikansi $<0,05(\alpha=5 \%)$. Hal ini berarti terdapat interaksi pengaruh antara teknik pembelajaran dan gaya belajar siswa terhadap hasil belajar afektif, berupa penanaman nilai nasionalisme, demokrasi dan multikultural.

Antara teknik pembelajaran dengan gaya belajar memiliki hubungan yang erat. Berdasarkan hasil analisis data dapat diketahui, ada kecenderungan bahwa teknik VCT lebih cocok digunakan oleh siswa auditori maupun visual, sedangkan teknik konvensional lebih cocok digunakan untuk siswa visual. Adanya interaksi tersebut dapat dilihat pada gambar berikut yang memperlihatkan adanya perpotongan grafik garis antara gaya belajar siswa, yakni auditori dan visual.

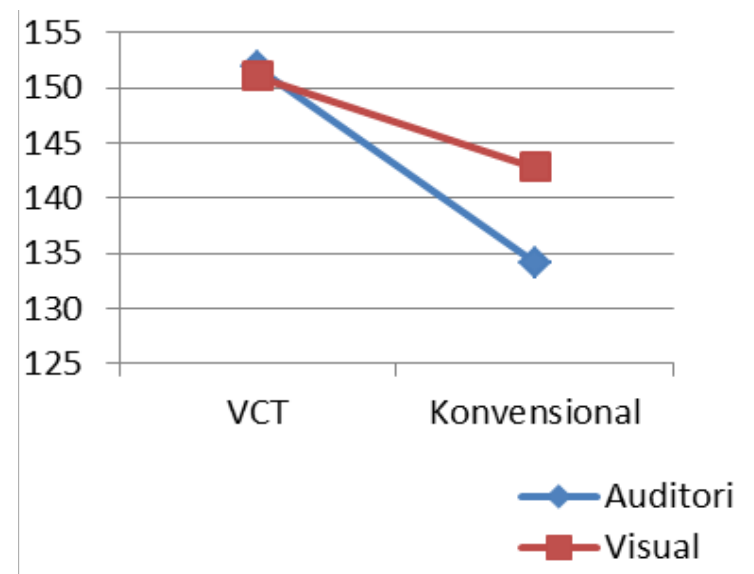

Gambar 2. Interaksi antara Gaya Belajar dengan Teknik VCT

\section{Simpulan dan Saran}

Simpulan

Berdasarkan hasil analisis data penelitian dapat disimpulkan: 1) Teknik pembelajaran VCT lebih efektif daripada teknik konvensional untuk meningkatkan nilai nasionalisme, demokrasi dan multikultural siswa dalam pembelajaran sejarah, 2) Dengan pembelajaran VCT maupun konvensional, pencapaian hasil belajar afektif siswa auditori lebih efektif dibanding siswa visual, 3) Dengan pembelajaran VCT, pencapaian hasil belajar afektif untuk siswa auditori relatif sama 
dibanding siswa visual, 4) Dengan pembelajaran teknik konvensional, pencapaian hasil belajar afektif siswa auditori tidak lebih efektif dibanding siswa visual, 5) pencapaian hasil belajar afektif untuk siswa auditori, pembelajaran VCT lebih efektif dibanding pembelajaran konvensional, 6) Pencapaian hasil belajar afektif untuk siswa visual, pembelajaran VCT lebih efektif dibanding pembelajaran konvensional, 7) Terdapat interaksi pengaruh teknik pembelajaran dan gaya belajar siswa terhadap hasil belajar afektif, berupa penanaman nilai nasionalisme, demokrasi dan multikultural.

Teknik klarifikasi nilai (VCT) efektif untuk penanaman nilai nasionalisme, demokrasi, dan multikultural melalui pembelajaran sejarah, baik pada siswa auditori maupun visual.

Saran

Berdasar hasil penelitian ini, maka disarankan untuk para guru: 1) Dalam melaksanakan pembelajaran sejarah yang memiliki muatan afeksi lebih menonjol dan dalam rangka membangun karakter bangsa, perlu mencoba menerapkan pembelajaran VCT, dengan menggunakan metode pembelajaran yang bervariasi agar siswa lebih tertarik untuk mengikuti pembelajaran, sehingga berdampak pada peningkatan hasil belajar afektif. VCT terbukti efektif dalam meningkatkan hasil belajar afektif siswa. 2) Guru perlu mengembangkan diri dalam mendesain pembelajaran secara kreatif dan inovatif, dengan memperhatikan berbagai aspek perkembangan siswa, baik kognitif, afektif, dan psikomotor secara seimbang. 3) Guru perlu mengidentifikasi karakteristik siswa seperti gaya belajar (visual, auditori, dan kinestetik), dan tipe kepribadian (introvert dan ekstrovert) sebelum memulai kegiatan pembelajaran, sehingga dapat melaksanakan kegiatan pembelajaran dengan memperhatikan karakteristik para peserta didiknya, 4) Guru perlu menciptakan iklim pembelajaran yang demokratis. Dengan suasana pembelajaran yang demokratis, siswa secara otomatis akan mengembangkan nilai-nilai demokrasi, dan multikultural, sebagai kebiasaan. Sikap guru yang demokratis merupakan bentuk keteladanan dalam upaya penanaman nilai demokrasi.

Penelitian ini memiliki keterbatasan dalam penentuan objek penelitian, sampel penelitian, waktu, dan penggolongan gaya belajar. Para Peneliti lain disarankan untuk menguji dengan penelitian lanjutan pada sampel yang berbeda atau setting yang berbeda.

\section{Daftar Pustaka}

Abd a'la. (November-desember 2002). Budaya lokal dan pemgembangan nasionalisme. Basis , 11-12, 46 -49

Acemoglu, Daron., Johnson, simon., Robinson, james A., et al. (2005) From Education to democracy?. The American economic review, 95,2, Proquest Research library pg. 44-49. Diambil tanggal 16 Agustus 2012 dari Proquest Educational Journal, http// search.proquest.com

Ahmad Syafi'i Maarif. (Mei-Juni 2001). Mencari otentisitas dalam kegalauan. Basis ,05-06, 4-7

Anwar Efendi. (Tanpa tahun). Gagasan nasionalisme dan wawasan kebangsaan dalam novel Indonesia modern. makalah seminar UNY. Diambil tanggal 12 desember 2012 dari http:/staff.uny.ac.id/.

Attarian,Aram. (Oktober 1996). Integrating values Clarification into outdoor adventure programs and activities. Journal of physical education, recreation \& dance.,67,8 proquest Pg 41-44 Diambil tanggal 16 Agustus 2012 dari Proquest education journals, http//search.proquest.com

Banks , A.James. (2007). Educating in a Multicultural Society. Amsterdam Avenue, New York: Teacher College press, Columbia University

Baskara $\mathrm{T}$ Wardaya. (November-Desember 2002). Nasionalisme humanis-universal: menjawab ajakan " pasca-nasionalis"nya Romo Mangun. Basis, 11-12, 38-45

Byford, Jeff \& Russell, William. (2006). Analyzing public issues-Clarification through discussion : a case study of Sosial study teachers.: Social studies review; fall 2006,46,1. Proquest education journals pg. 70-72. Diakses tanggal 16 Agustus 2012 dari, http//search.proquest.com 
Daliman, A. (2004). Perspektik pendidikan sejarah yang ideal. Yogyakarta : Makalah seminar pendidikan sejarah di era pembangunan oleh Kementerian Kebudayaan dan pariwisata bekerjasama dengan Balai kajian sejarah dan nilai tradisional Yogyakarta dan proyek pemanfaatan kebudayaan daerah DIY.

Darmiyati Zuchdi. (2008). Humanisasi pendidikan. Jakarta : Bumi Aksara

De Porter, Bobbi. \& Hernachi, Mike. (2002): Quantum learning, membiasakan belajar nyaman dan menyenangkan. (terjemahan Alwiyah Abdurahman). Bandung: Kaifa (Buku asli diterbitkan tahun 1992. New York:Dell Publishing)

Farida hanum. (2012). Multikulturalisme dan pendidikan. Makalah seminar. Di ambil tanggal 15 Agustus 2012 dari staff.uny. ac.id

Gutman, Amy. (1999). Democratic education. Princeton, New Jersey: Princeton University press.

Irwan Abdullah. (2000). Kondisi sosial yang dibayangi disintegrasi tanpa ujung. Jakarta: Dalam Ninok leksono (ed). Indonesia abad XXI di tengah kepungan perubahan Global. Jakarta : PT Kompas media nusantara

Kirscherbaum, Howard. (2000). From Values Clarification to Character Education : a personal journay. Journal of humanistic counseling, education and development. September 2000;39,1. Proquest Educational Journals Pg 4- 20. Diambil tanggal 16 Agustus 2012 dari: http//search. proquest.com

Lickona, Thomas. (1991). Educating for character: How our schools can teach respect and responsibility. New York: bantam book

Mochtar Buchori. (2001). Pendidikan antisipatoris. Yogyakarta: Kanisius

Mosconi, Jacqueline \& Emmett, Judith .(2003). Effect of a Values Clarification
Curriculum on High school Students' Definitions of Success.Profesionqal school counseling;Dec 2003, 7,2; Proquest education journals pg 68-78 Diambil tanggal 16 Agustus 2012. Dari http//search.proquest. com

Pupu Saeful Rahmat. (Juli-Desember 2007). Wacana pendidikan multikultural di Indonesia. Equilibrium,3, 1-7

Sardiman AM. (2004). Kebijakan dan strategi pendidikan sejarah di era reformasi. Makalah diskusi Sejarah di era pembangunan yang diselenggarakan oleh kementerian kebudayaan dan pariwisata bekerja sama dengan Balai kajian sejarah dan nilai-nilai tradisional Yogyakarta

Sudrajat. (2011). Mewujudkan insan cendekia mandiri dan bernurani melalui metode Values Clarification Technique dalam mata kuliah sejarah local pada jurusan pendidikan sejarah FISE UNY. Jurnal SOCIA No. 1. Tahun 2011. Di akses tanggal 15 Agustus 2012 dari staff.uny.ac.id. Pdf

Sutarjo Adi Susilo, JR. (2012). Pembelajaran nilai-nilai karakter: konstruktivisme dan VCT sebagai inovasi pendekatan pembelajaran afektif. Jakarta: PT Raja Grafindo Persada.

Tilaar, H.A.R. (2002). Perubahan social dan pendidikan, Pengantar pedagogic transformative untuk Indonesia. Jakarta : PT Gramedia Widyasarana Indonesia bekerjasama dengan Center for Education and Community Development Studies

Zamroni. (2003). Pendidikan untuk demokrasi, tantangan menuju civil Society. Yogyakarta : Penerbit BIGRAF Publising.

(2007). Pendidikan dan demokrasi dalam transisi, Prakondisi menuju era globalisasi. Jakarta : PSAP Muhamadiyah.

(2011). Pendidikan demokrasi pada masyarakat multikultural. Yogyakarta: Gavin Kalam Utama. 